\section{Phalaropes in Central Borneo}

LITTLE is known of the movements of the northern phalarope (Phalaropus lobatus L.) which winters in large numbers in the seas south of Borneo. None has been recorded for Malaya, and until recently it was not known from Borneo itself.

In $1945-49$, I found it an abundant passage migrant on the upland area of the far interior, inhabited by the Kelabits between 3,000 and 4,000 ft. ${ }^{1}$. The earliest arrival was October 10, the latest November $5(1949)$. The birds, in full winter plumage, are so tame that they sit in the irrigated rice plots and allow themselves to be picked off by small boys using the 6 -ft. blowpipes with which Kelabits are most expert.

Three specimens have also been taken farther south in the interior, all in October or November, one in a little stream on Mt. Dulit at $4,000 \mathrm{ft}$. In October 1945, I nearly touched another with a paddle while canoeing down the Baram River in central Dutch Borneo, at about 2,000 ft.

None is known from the lowlands.

TOM HARRISSON

The Sarawak Museum,

Kuching, Sarawak.

May 25

${ }^{1}$ Harrisson, T., Geog. J. 114, 129 (1949).

\section{South Pacific Chlorophycea}

A REvISION of the marine Myxophyceæ of New Zealand has resulted in the addition of many species, none new, to the flora. A similar revision of the Chlorophycer has revealed the fact that even in this well-known group the flora of the South Pacific is probably the most profitable field for phyeologists. The new discoveries include a new genus of the Ulvales with five species, three of which are restricted to Stewart Island and the southern Antarctic dependencies. In this remarkable new genus the cells, which are small in surface view, are commonly in pairs (hence it is proposed to call the genus Gemina) and are excessively elongated vertically. They are also extruded very readily from the matrix of the lamina. The other interesting feature is the manner in which the species simulate other genera of the Ulvales. Thus one species has the appearance of an Enteromorpha, two have the appearance respectively of orbicular and lanceolate species of Ulva and a fourth is like a Letterstedtia.

The genus Ulva has also proved a rich source of new species, in many cases differing markedly from existing species. Cultural studies of two of the new species may result in their transfer to a now genus, because herbarium material suggests that the reproductive cells differ from the vegetative cells and are restricted to the centre portion of the thallus. In gross appearance these two species are not unlike $U$. linza and $U$. toeniata. Other genera rich in new species are Monostroma, Chotomorpha and Rhizoclonium, the latter being very interesting in possessing one species at least that might almost be mistaken for a Cladophora.

The genus Bryopsis is also very rich in new species, so much so that one must suspect that either active evolution is progressing in these waters or else that the genus originated in the South Pacific. The new species have only been created after comparison with material of the other known species, in which con- nexion thanks are due to Profs. Papenfuss and Mason of the University of California for loan of material.

It is hoped to publish the sections dealing with the Myxophyceæ and Chlorophyceæ (including all the new species) this year. The revision has been facilitated by access to the Laing collection (kindly loaned by Canterbury College), the collection of the Plant Research Bureau and the private collection of Mr. V. W. Lindauer.

University College, Auckland, N.Z.

Feb. 13.

\section{Effect of Sowing Time and Photoperiods in Sorghum Roxburghii var. hians, Stapf. (Jowar)}

SEEDS of Sorghum Roxburghii var. hians were sown for one year at intervals of one month commencing February 15, 1949. Owing to a limited number of available seeds, about twenty seods were sown in single small plots (5 ft. $\times 3 \mathrm{ft}$.). Although there was $a$ good percentage of germination in all the sowings except those of November 15, 1949, December 15, 1949 , and January 15, 1950, only a limited number of plants varying between three and nine for the different sowings survived until the flowering stage. The date of first emergence of the panicle out of the top flag leaf taken as the flowering date and the height at flowering were noted separately for each plant, and the mean data are given in Table 1.

Table 1. EFFECT OF SowIxg TIME IN Sorghum Roxburghii var. hians

\begin{tabular}{|c|c|c|c|}
\hline Date of sowing & $\begin{array}{l}\text { Mean height in } \\
\text { cm. at flowering } \\
\text { stage }\end{array}$ & $\begin{array}{l}\text { Mean date } \\
\text { of } \quad \text { towering }\end{array}$ & $\begin{array}{l}\text { Mean flowering } \\
\text { time in days } \\
\text { after sowing }\end{array}$ \\
\hline Fab. 15,1949 & $527 \cdot 0$ & 25.10 .49 & 253 \\
\hline March 15,1949 & $504 \cdot 33$ & 25.10 .49 & 224 \\
\hline April 151949 & $377 \cdot 40$ & 25.10 .49 & 194 \\
\hline May 15,1949 & $375 \cdot 42$ & 24.10 .49 & 163 \\
\hline June 15,1949 & $306 \cdot 66$ & 25.10 .49 & 132 \\
\hline J uly 15,1949 & \multicolumn{3}{|c|}{ All plants died due to excessive rainfall } \\
\hline Aug. 15, 1949 & $247 \cdot 86$ & 2.11 .49 & 79 \\
\hline Sept. 15,1949 & $182 \cdot 85$ & 26.11 .49 & 72 \\
\hline Oct. 15,1949 & $117 \cdot 00$ & 18.12 .49 & 64 \\
\hline Nov. 15,1949 & $\begin{array}{l}\text { Only a few seeds } \\
\text { at young stage. }\end{array}$ & germinated but & the plants died \\
\hline $\begin{array}{l}\text { ec. } 15,1949 \\
\text { n. } 15,1950\end{array}$ & $\begin{array}{l}\text { No germination } \\
\text { No germination }\end{array}$ & & \\
\hline Jan. 15,195 & No germination & & \\
\hline
\end{tabular}

The death of all the plants sown in July may be ascribed to practically incessant rainfall for fifteen days before and after the sowing, and want of growth or germination in the plants sown in November, December and January to comparatively lower temperature at the period; although when sown in pots in December there was germination and growth, but very much checked.

It will be seen that for widely different sowing times between February and June, the flowering takes place on October 24 or 25 when the daily light period becomes $11 \mathrm{hr} .28 \mathrm{~min}$., and there is a gradual decrease in the flowering time and height at flowering with the lateness of sowing. The sowings of August, September and October flowered in November and December; but the flowering time and height are gradually shortened with the lateness of sowing.

Sown in earthenware pots 13 in. diameter and $13 \mathrm{in}$. height in March, the plants were exposed. commencing at the age of nine days to $8 \mathrm{hr}$., $10 \mathrm{hr}$., $12 \mathrm{hr}$., $14 \mathrm{hr}$. and $16 \mathrm{hr}$. light periods, the shortening of the light period being done by transferring the pots to a ventilated dark room for the required period before sunset and bringing them out again after dusk; 